University of Nebraska - Lincoln

DigitalCommons@University of Nebraska - Lincoln

USDA Wildlife Services - Staff Publications

U.S. Department of Agriculture: Animal and Plant Health Inspection Service

2016

Feral swine damage to globally imperiled wetland plant communities in a significant biodiversity hotspot in Florida

Richard M. Engeman

USDA-APHIS-Wildlife Services, s_r100@yahoo.com

Steve L. Orzell

Avon Park Air Force Range

Rodney K. Felix

USDA/APHIS/WS National Wildlife Research Center

Eric A. Tillman

USDA/APHIS/WS National Wildlife Research Center, eric.a.tillmann@aphis.usda.gov

Gary Killian

USDA/APHIS/WS National Wildlife Research Center

See next page for additional authors

Follow this and additional works at: https://digitalcommons.unl.edu/icwdm_usdanwrc

Part of the Life Sciences Commons

Engeman, Richard M.; Orzell, Steve L.; Felix, Rodney K.; Tillman, Eric A.; Killian, Gary; and Avery, Michael L., "Feral swine damage to globally imperiled wetland plant communities in a significant biodiversity hotspot in Florida" (2016). USDA Wildlife Services - Staff Publications. 1846.

https://digitalcommons.unl.edu/icwdm_usdanwrc/1846

This Article is brought to you for free and open access by the U.S. Department of Agriculture: Animal and Plant Health Inspection Service at DigitalCommons@University of Nebraska - Lincoln. It has been accepted for inclusion in USDA Wildlife Services - Staff Publications by an authorized administrator of DigitalCommons@University of Nebraska - Lincoln. 


\section{Authors}

Richard M. Engeman, Steve L. Orzell, Rodney K. Felix, Eric A. Tillman, Gary Killian, and Michael L. Avery 


\title{
Feral swine damage to globally imperiled wetland plant communities in a significant biodiversity hotspot in Florida
}

\author{
Richard M. Engeman ${ }^{1}$ - Steve L. Orzell ${ }^{2}$ Rodney K. Felix ${ }^{3,4}$. \\ Eric A. Tillman ${ }^{3}$ - Gary Killian ${ }^{1}$ Michael L. Avery ${ }^{3}$
}

Received: 14 January 2016/Revised: 20 May 2016/Accepted: 20 June 2016/ Published online: 29 June 2016

(C) Springer Science+Business Media Dordrecht (out side the USA) 2016

\begin{abstract}
We studied rooting damage during five-years of feral swine control at Avon Park Air Force Range, a significant botanical biodiversity hotspot in peninsular Florida with many globally imperiled plant species and communities. While control reduced swine abundance, remaining animals consistently rooted the 49 studied sites in both middle-dry season (MDS) and late-dry season (LDS) each year. At each study site, we measured rooting with sub-meter accuracy. Neither total nor proportional area rooted differed in either season, across study years, or among plant community types: herbaceous seepage slopes, wet pine savannas, wet grasslands. The proportion of sites with damage during MDS was at least $25 \%$ less than pre-control baseline. During LDS, the proportion of sites with damage increased over years but remained below the initial 2 years' MDS results. Fresh rooting frequency (rooting $<1$ week-old) across sites dropped precipitously from baseline and remained low for MDS. Fresh rooting frequency among sites during LDS was lower than MDS for all but year two of the study. Canopied habitat $<50 \mathrm{~m}$ from a study site almost guaranteed rooting at the site each observation period. We propose actions for protecting wetlands, integrating swine control into other compatible land use practices, and improving swine control efficacy. While we measured damage amounts at each site very accurately, our approach of also considering frequency of rooting and frequency of fresh rooting across sites offers low-labor means to broadly assess swine damage and control
\end{abstract}

Communicated by B. D. Hoffmann.

Richard M. Engeman

richard.m.engeman@aphis.usda.gov

1 USDA/APHIS/WS National Wildlife Research Center, 4101 LaPorte Ave, Fort Collins, CO 80521-2154, USA

2 Avon Park Air Force Range, 29 South Blvd., Avon Park AFR, FL 33825, USA

3 USDA/APHIS/WS National Wildlife Research Center, Florida Field Station, 2820 E University Blvd., Gainesville, FL 32641, USA

4 Present Address: Eglin AFB Natural Resources-Wildlife, 107 SR 85 North, Niceville, FL 32578, USA 
efficacy at large geographic scales because in-field measurements of damage amounts are not needed.

Keywords Animal damage - Biodiversity - Endemic and endangered plants - Invasive species $\cdot$ Seepage slopes $\cdot$ Sus scrofa

\section{Introduction}

Subtropical peninsular Florida provides an ideal environment for the establishment of invasive species (Engeman et al. 2009), as demonstrated by Florida having more introduced animals than any other region of the continental USA and ranking high in this respect globally (Hardin 2007). Feral swine (Sus scrofa) can be considered among the more notorious invasive species threatening the health of Florida's natural resources (e.g., Engeman et al. 2007a, b; Hardin 2007; Rodgers et al. 2014; Seward et al. 2004). Swine were among the first invasive species to establish in Florida (and therefore North America) after being introduced by DeSoto in 1539 (Towne and Wentworth 1950). Feral swine possess the highest reproductive potential of any large mammal in North America (Wood and Barrett 1979; Hellgren 1999) and their range and numbers in the U.S. continue to increase (Corn et al. 2005; Gipson et al. 1997). Feral swine degrade habitats and archaeological sites, prey on native species, and compete with native species (Choquenot et al. 1996; Engeman et al. 2013a; Seward et al. 2004; Taft 1999; U.S. Department of Agriculture 1999). They also harbor a number of diseases transmittable to wildlife, livestock, or humans (e.g., Conger et al. 1999; Corn et al. 2005; Romero and Meade 1999; Taft 1999). Feral swine inhabit many areas in such large numbers that they adversely impact wildland and agricultural ecosystems.

Damage to sensitive habitats by feral swine is perhaps most noticeable and pronounced in wet and seasonally wet environments (e.g., Choquenot et al. 1996). In Florida, wetlands are rapidly disappearing (Florida Natural Areas Inventory 2010; Myers and Ewel 1990). For example, only $1 \%$ of the original extent of seepage slopes remain in Florida (Engeman et al. 2007b; Florida Natural Areas Inventory 2010).

Feral swine often reduce their foraging sites to bare, overturned and excavated soil (Groot Bruinderink and Hazebroek 1996; Chavarria et al. 2007). They combine their keen sense of smell with their rooting ability to excavate subterranean environments for food sources (e.g., Bratton et al. 1982; Baber and Coblentz 1987; Hone 1988). Feral swine consume and destroy vegetation, especially grasses, sedges, forbs, and some shrubs and trees (Taylor and Hellgren 1997; Cole et al. 2012). Moreover, rooting alters the provenance of the area (Groot Bruinderink and Hazebroek 1996; Cole et al. 2012; Boughton and Boughton 2014), and increases its ecological invasibility by exotic species, thereby threatening plant biodiversity (Kotanen 1995; Cushman et al. 2004). Feral swine are considered by some to be the single greatest vertebrate modifier of natural plant communities (Bratton 1977; Wood and Barrett 1979).

Avon Park Air Force Range (APAFR) in south-central Florida is recognized as a significant conservation area (Orzell 1997; Stein et al. 2008) within a region considered a hotspot for biodiversity (Noss et al. 2015). The base contains extensive wetlands, globally rare plants, and unique plant communities, many of which are endemic to peninsular Florida. For example, extensive intact landscapes of cutthroat grass, (Coleataenia 
abscissa), a peninsular Florida endemic perennial C4 grass dominates ridge-associated wetlands, and some wet grasslands and savannas on APAFR (Bridges and Orzell 1999; Orzell 1997). Feral swine consistently damage these ecologically sensitive sites through their extensive rooting behavior. Despite recreational hunting, which is popular with the public at APAFR, persistent feral swine damage to priceless plant communities prompted additional efforts to reduce the feral swine population through implementation of a control program. We conducted a five-year study to determine if a control program could reduce the feral swine population and curtail damage to sensitive wetlands. Ideally, feral swine control would reduce or eliminate damage. However, unless feral swine are permanently eradicated or excluded (fenced) from sensitive areas, damage can be expected to continue at some level. APAFR is permeable to immigration from adjoining lands (including an adjacent private property where swine are released for hunting) and fencing all the wetlands ( 22,000 ha, $50 \%$ of APAFR) in an ecologically functional manner has not been deemed efficient or economically feasible to this point. We report here on findings from this five-year endeavor.

Supporting this investigation, Felix et al. (2014) first developed an approach for obtaining highly accurate swine damage measurements addressing the spatial and temporal aspects of rooting. Also, monitoring population changes is a key performance metric for evaluating the need and efficacy of management actions and Engeman et al. (2014) applied three metrics to monitor the impacts of control on feral swine population levels at APAFR through the same time course as our damage observations.

\section{Methods}

\section{Study area}

Established during World War II for air to ground training and related military missions, APAFR is a 42,430 ha military installation with 23,600 ha of intact landscape (Orzell 1997). APAFR has fifty-five species listed as either state or federally (U.S.) threatened or endangered (Ebersbach et al. 2013), including many state and globally imperiled plants $(<20$ sites exist globally). The base is the cornerstone of conservation lands in southcentral Florida due to its size, and when considered with neighboring environmental lands collectively, provides protection to over 319,700 ha harboring biodiversity of global significance (Stein et al. 2008; Noss et al. 2015; Sorrie and Weakley 2001, 2006). APAFR flora includes $>40 \%$ of the native flora known in central Florida, with many narrowly- or regionally-endemic plants with restricted ranges. The landscape varies from lowland longhydro-period marshes along the Kissimmee River (elevation $9.1 \mathrm{~m}$ ), to pine savannagrasslands with embedded short-hydro-period marshes on poorly drained higher flatlands, to herbaceous seepage slopes and forested seeps on the mucky sideslopes of Bombing Range Ridge (bisecting APAFR longitudinally, Fig. 1), to xeric sandy ridge-top uplands (up to $41.2 \mathrm{~m}$ ). Some of the highest fine-scale species richness values recorded in North America (27 in $0.1 \mathrm{~m}^{2}, 49$ in $1 \mathrm{~m}^{2}$, and 171 in $1000 \mathrm{~m}^{2}$ ) have been documented in groundcover vegetation of pine savanna-grasslands at APAFR (Orzell and Bridges 2006a). Additionally, many plant community types are globally imperiled and are dominated by endemic plant associations not found outside of peninsular Florida (Orzell 1997). The base continues to produce discoveries of as-yet undescribed plant species and previously 


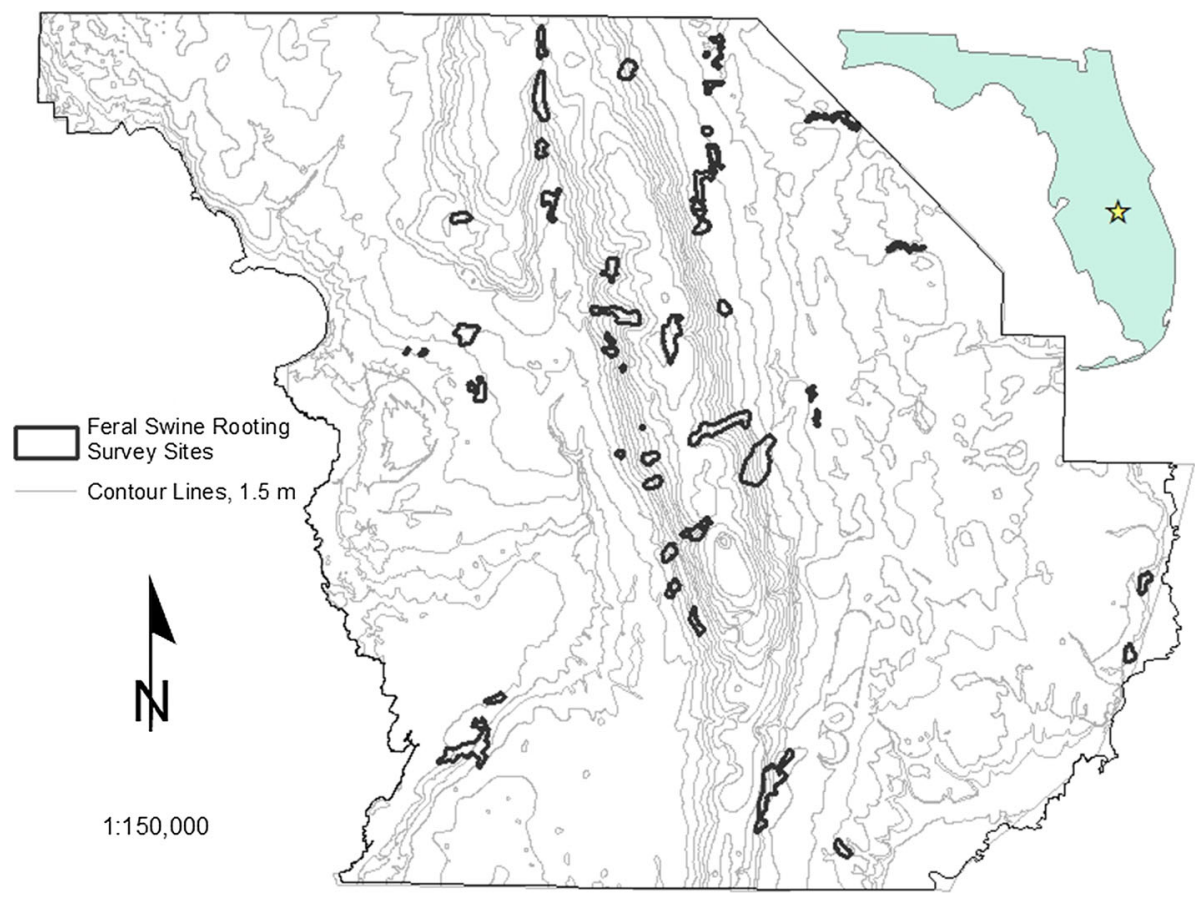

Fig. 1 Forty-nine feral swine rooting survey sites (587 ha total) at Avon Park Air Force Range, located in south central Florida. Most closely placed contour lines define bombing Range Ridge, a prominent topographical feature running longitudinally through the center of the installation that contributes greatly to the plant biodiversity documented within the range

undetected globally rare fauna and flora, a hallmark of biodiversity hotspots (Joppa et al. 2011).

APAFR has a humid subtropical climate, with a winter dry, and summer wet seasons (Chen and Gerber 1990; Slocum et al. 2010). The duration of the wet season averages 133 days from May to October. The dry season, despite being almost twice as long, has only half the rainfall, thereby depleting soil moisture and lowering water levels, which is especially pronounced in wetlands subjected to seasonal inundation. The El Niño Southern Oscillation (ENSO) cycle accentuates or diminishes the effects of seasonal precipitation in the region (Slocum et al. 2010; Slocum and Orzell 2013). During the La Niña phase of ENSO, reduced precipitation creates severe drought during the dry season (Brenner 1991; Beckage et al. 2003), whereas during the El Niño phase, dry season precipitation increases (Donders et al. 2005, 2011; Slocum and Orzell 2013). Intra-annual variation in the wet/dry seasonal climates and variations in the ENSO cycle influence hydrology and affect the hydro-period within seasonal wetlands, pine savannas, and grasslands. Even subtle elevation differences create a hydro-edaphic gradient from wet to xeric plant communities. The gradient is further enhanced by pronounced seasonal differences in precipitation and subsequent changes in soil moisture content within differing plant communities. The seasonal soil moisture gradient across the landscape may strongly influence rooting behavior, and thus damage, in some plant communities. For example, during the late dry season when aboveground biomass and acorn production are diminished, feral swine often 
root for moist carbohydrate rich underground storage organs (i.e. roots, corms, rhizomes, xylopdia, etc.) and soil invertebrates in mucky and peaty histosols of seepage slopes. In contrast feral swine are attracted to seasonally wet (but not flooded) pine savannas and grasslands when wetlands are inundated during the late wet season.

\section{Characterization of plant community study sites}

Sampling commenced during the winter dry season, December 2008-January 2009. Thereafter, we sampled annually during November-January [middle-dry season (MDS)] through 2013, and during April-May [late-dry season (LDS)] through 2012. Sampling during the summer wet season was impractical, because sites were often inundated and access routes flooded. The MDS observations retained and captured important wet season conditions, such as elevated soil moisture and inundated wetlands from the previous wet season. The LDS sampling provided observations during the dry season conditions of low soil moisture and dry wetlands.

In total, 49 sensitive plant community sites were selected for study. Due to start-up logistics, we initially were able to consider 36 of the plant sites for study. Two of these sites had to be eliminated due to access restrictions. At the fourth sampling (LDS 2010), we included the additional 15 sites to create the total of 49 sites (ranging in individual areas from 0.63 to 60.14 ha) (Fig. 1). Each site met at least one of three criteria: (1) a history of feral swine rooting activity; (2) presence of rare plant species, or (3) presence of imperiled sensitive plant community. We broadly categorized sample sites as herbaceous seepage slopes ( $\mathrm{SS} ; \mathrm{n}=26,451$ ha-total area), wet pine savanna (WS; $\mathrm{n}=14,62$ ha-total area); wet grasslands (WG; $\mathrm{n}=5,22$ ha-total area), and wet pine savanna-wet grasslands mosaics (WSG; $\mathrm{n}=4,52$ ha-total area).

Wet pine savannas occur on poorly drained sandy spodosols that are often saturated during the wet season but may be desiccated during the dry season. Wet pinelands have a scattered or moderately dense canopy of either longleaf pine (Pinus palustris), south Florida slash pine (Pinus elliottii var. densa), or both, with an exceptionally diverse groundcover typically dominated by wiregrass (Aristida beyrichiana) and toothache grass (Ctenium aromaticum), or by cutthroat grass and shrubs such as gallberry holly (Ilex glabra) or wax-myrtle (Morella cerifera).

Wet grasslands, are essentially low-lying treeless areas within the pine savanna landscape, with a 2-4 month wet period, and occur on spodosols or wet sandy entisols often with a shallow muck or mucky sand soil surface (Orzell and Bridges 2006b). The ground cover is species-rich consisting of perennial $\mathrm{C} 4$ grasses (40\% or greater mean cover), sedges, and forbs, with little or no shrub cover when frequently burned (Orzell and Bridges 2006b). Although the dominant Aristida beyrichiana is cespitose, many of the grasses in the wet grasslands are rhizomatous or stoloniferous. The 4 study sites that were mosaics of pine savannas and wet grasslands shared characteristics of both.

Herbaceous seepage slopes occur on the sideslopes of the Bombing Range Ridge (Fig. 1), where there is constant groundwater seepage, on mucky or mucky peat histosols. Some seeps are dominated by the endemic cutthroat grass. At APAFR, the seepage slopes support large populations of the globally rare Florida endemic Hartwrightia floridana. Moreover, $23 \%$ of the plants found in APAFR seeps are either endemic or near-endemic to Florida (Bridges and Orzell 1999). The mixed herbaceous seepage slope is typically dominated by $A$. beyrichiana and $C$. aromaticum, with a mixture of sedges and herbaceous species. The mixed herbaceous seepage slopes support many disjunct plants that are rare in south-central Florida and at their southernmost range limit. South-central peninsular 
Florida herbaceous seepage slopes are floristically distinct from other southeastern United States coastal plains seepage bogs and are considered globally imperiled, with most remaining high-quality intact examples now confined to APAFR (Bridges and Orzell 1999).

\section{Quantifying damage}

During each seasonal survey (MDS and LDS), we systematically walked the sites on parallel transects, typically $20-30 \mathrm{~m}$ apart, spaced according to the visibility permitted by ground cover. This transect spacing enabled us to detect virtually all rooting within a site. We used navigation and mapping functions within each hand-held GPS unit to maintain parallel transects while traversing the uneven terrain. When we encountered swine rooting, we used the hand-held GPS unit $\left[\mathrm{GeoXT}^{\mathrm{TM}}\right.$ GPS receivers (Trimble 2008), or a MobileMapper ${ }^{\mathrm{TM}}$ CX GPS receiver (Ashtech 2009)] to log our position continuously as we walked the perimeter of the rooted area to create a polygon. We also entered the percentage of the polygon that was actually rooted as needed, since some otherwise-rooted areas contained remnants of unaltered vegetation. In such cases, we estimated the percentage of the total area that was undisturbed to avoid over-quantifying the amount of feral swine damage. Although we noted various signs of swine activity other than rooting, we did not include them as measures of impact to sites (feces, trails/tracks, rubs, and sightings of individuals).

We converted the rooting polygon data to GIS-compatible files, using GPS Pathfinder Office $^{\mathrm{TM}}$ (Trimble 2008) and Mobile Mapper Office ${ }^{\mathrm{TM}}$ (Ashtech 2009), and processed them in ArcMap (ESRI 2011). We used GIS to compute metrics such as rooting polygon area and area rooted. A protocol for assessing the age category of rooted patches had been developed (Felix et al. 2014), but many climatic and geophysical factors make precise age assessments challenging. Nevertheless, we felt very confident that fresh ( $\leq 1$ week-old) damage was accurately distinguishable from other age classes (Felix et al. 2014). Briefly, damage $\leq 1$ week old was characterized by: the bare overturned soil in the rooted area having no plants sprouting, the overturned vegetation was still green, exposed roots of overturned vegetation were intact and pliable, disturbed vegetation had not re-sprouted, the soil texture was fluffy and moist (Felix et al. 2014). Moreover, $\leq 1$ week-old damage represents a snapshot view of more temporally immediate damage rates, which is a perspective we wanted to assess analytically.

\section{Analytical concepts}

We were interested in two analytical approaches. We made highly accurate damage measurements, and therefore, the first approach was to analyze damage magnitudes (for both all damage and fresh damage) found in the sites, either as a measured amount or as a proportion of site area. The second approach involved treating damage observations (again, for both all damage and fresh damage) as a binary, presence-absence variable, which we used to evaluate probabilities that sites (proportions of sites) would be damaged on each observation occasion. This overview approach helped us consider and identify risk factors and patterns of damage, while also identifying appropriate means for analyzing damage magnitudes. For example, we were able to assess if the probability for damage might differ between seasons, given that different seasons can present differing soil moisture contents, 
alternative food sources, plant characteristics, and soil organisms that might affect rooting behavior. We also were able to single out potential risk factors like proximity to canopied cover or a recent fire to see if they might affect the chance that a site would receive damage.

An important consideration for all analyses was that there were 34 sites that were monitored since the inception of the study, with 15 more added at the fourth observation period. The first two observation periods, during MDS in December 2008-January 2009 and LDS in 2009, were made just before or just as the feral swine control program was initiating, and thus represented pre-swine control baseline observations. All other observations were made after control had been taking place. Hence, only the initial 34 plant community sites had repeated observations from pre-control, and therefore were the only sites available for pre-control comparisons. These observations were the ones used for evaluating the longitudinal impacts of swine control on rooting damage across years. When examining results within the individual years, we used data from all available sites together, meaning data from the original 34 sites were used for analyses within the first three observation periods, whereas we used data from all 49 sites from the fourth observation period on.

\section{Analytical methods}

We were principally interested in analyzing the impact of the swine control program over time on the frequency and amount of damage to the different plant community types during the MDS and LDS time frames. Feral swine population monitoring indicated an initial steep decline at APAFR through 2010, but stable or slightly increasing population trend thereafter. The population remained well below initial levels, but far from depletion or eradication (Engeman et al. 2014). Thus, feral swine were always available to damage sensitive plant sites.

Besides the influences of the swine control program, we also examined whether other factors might have influenced risk of how frequently plant communities would be damaged.

- Proximity to cover We defined close proximity as $\leq 50 \mathrm{~m}$, as this distance to highquality cover (i.e., canopied habitats) was a potential distinguishing factor among the plant community sites. Increasing the distance as a defining feature not only decreased the relevance of the cover as a refuge near a particular plant community site, but also resulted in multiple plant sites sometimes associated with the same cover.

- Burn history Another possible influence on our damage observations was that human ignitions might affect the probability of damage by feral swine. Human ignitions (prescribed and military mission-caused) and lightning ignited wildfires maintain the humid savanna-grassland landscapes at APAFR and in these ecosystems worldwide (Platt et al. 2015). We considered the possibility that frequent fire might have a gross deterrent effect on feral swine rooting, particularly if a site had been recently burned. A spatial database maintained by the base detailed the specific coverage and timing of all ignitions. At each observation period we used this database to categorize whether or not each site had been impacted by a fire that could have reasonably been expected to have influenced whether it was rooted.

- Adjacent property The location of a sensitive plant community site near the northern border of the base might be a potential risk factor, because the adjacent property is a private hunt club where feral swine are sporadically released. Such releases represent 
an increased opportunity for immigration into the base beyond what might occur naturally among the feral swine living in the vicinity. Previously, Engeman et al. (2014) found strong evidence of immigration from that property, implying there might have been artificially increased pressure on the northern plant sites before immigrant swine diffused through the base. Thus, we compared the average proportion of sites with any feral swine damage across years at sites located within $1.6 \mathrm{~km}$ of the north border to the average proportion of sites with any feral swine damage located throughout the rest of the base. If another risk factor for damage was found to be a nearcertain indicator of damage, then those sites found to have that risk factor were excluded from these analyses so as not to confound the influence of the north border.

At each sampling we knew very precisely the amount of rooting within each studied plant community, including the amount of fresh damage $\leq 1$ week in age. Because of the wide range in sizes among the sampled plant communities, the same amount of damage represented different impacts (proportion of area) among the different sites. Thus, we also considered proportion of area damaged (for both total damage and fresh damage) at each site on each occasion as equally important as the absolute amount damaged for analytical purposes.

As indicated in Analytical concepts, above, in addition to the amount and proportion of area damaged, the categories of whether or not a site had damage and whether it had fresh damage provided additional important evaluation approaches. While this binary approach of presence or absence of damage and fresh damage does not encompass the actual magnitudes of damage at each site, it does present a relatively quick, low-labor overview of the distribution and pattern of damage among sites over a wide geographic area.

Prior to evaluating the effects that feral swine control might have had on the frequency of damage occurrence and frequency of fresh damage occurrence at the sensitive plant sites, we first considered whether there might be seasonal differences in the probability of damage between MDS and LDS timeframes within each year, except for 2013, when this study concluded with the MDS observations. Because each site was observed in both timeframes each year, we applied McNemar's test to compare for differences in frequency of damage and also frequency of fresh damage between seasons each year. Based on differences in probability of damage between timeframes, we subsequently evaluated the probability of damage across years separately for the MDS and LDS timeframes using Cochran's Q test (using the original 34 sites with observations each year). Within each year and each MDS and LDS observation period, we used all available observations each year to compare frequency of damage and also frequency of fresh damage among community types using Fishers "exact" test (necessary because the wet prairie and wet flatwoods/wet prairie mosaics sites were too few in number to offer valid $\chi^{2}$ contingency table tests). For each of the 34 sites observed on each sampling occasion, we calculated the proportion of the sampling occasions (two per year) where damage was observed. We compared the mean proportions of occasions where damage was observed between sites near the north border with sites found throughout the rest of the base using a two-sample $t$ test. The magnitude of damage within a site and the proportion of the site damaged were analyzed separately for the MDS and LDS timeframes using a two-factor repeated measures ANOVA where sites were nested in plant community type and year was the repeated factor. 


\section{Results}

\section{Proportion of sites with feral swine damage}

The proportion of sites with any damage was different between the MDS and LDS for the first 2 years of study, but could not be distinguished thereafter (Table 1), while differences in fresh damage rates between seasons were only apparent in the first and third years (Table 2). These results suggest the probability of any damage or fresh damage was not consistent between seasons.

Considering the original 34 sites, the proportion of sites having any age of damage varied through time for both the MDS and the LDS (Table 3). For MDS, the proportion of sites with damage declined each year from 2010 to 2012, but increased in 2013, although it still was $25 \%$ less than what was originally observed in 2008-2009 (pre-control baseline, Table 3). The proportion of sites with damage during the LDS tended to increase from 2009 , but with all values still at least $11 \%$ less than the maximum value during the MDS (Table 3).

The proportion of sites with fresh damage ( $\leq 1$ week age) was 0.62 during the MDS in the initial year (pre-control baseline, 2008-2009), dropped precipitously the next year, and always remained $\leq 0.27$ thereafter. Thus meaning it never reverted beyond $43 \%$ of the baseline (Table 3). During the LDS, when the proportion of sites with damage increased over time, the proportion of sites with fresh damage started very low, increased to a maximum in the second year, and then declined (Table 3). At APAFR, the feral swine population trended downward during the first 2 years of control, and then stabilized (Engeman et al. 2014). Thus, there always were enough feral swine to cause damage, potentially explaining the mixed results for the proportion of sites with damage. However, the probability that at any time a given site would be rooted may have been reduced, potentially explaining declines in the proportion of sites with fresh damage.

Differences in the proportion of sites with damage among the plant community types were not detected except during the MDS in 2013 (Table 4). Similarly, differences in the proportion of sites with fresh damage among plant community types did not occur except during the MDS in 2010 (Table 5). Thus, there was little to suggest a pronounced preference or avoidance between plant community sites for feral swine to root.

Table 1 Annual comparisons of the proportion of sites with any feral swine damage between seasons at sensitive wetland plant community sites on Avon Park Air Force Range, Florida

\begin{tabular}{lllllll}
\hline Sites used & Year & \multicolumn{2}{l}{ Season } & & \multicolumn{2}{l}{ McNemar's test } \\
\cline { 6 - 7 } & & MDS & LDS & & $\chi^{2}(1 \mathrm{df})$ & $\mathrm{p}$ \\
\hline Initial 34 & $2008-2009$ & 0.82 & 0.35 & 14.22 & 0.0002 \\
& $2009-2010$ & 0.76 & 0.53 & 5.33 & 0.0210 \\
All 49 & $2010-2011$ & 0.67 & 0.71 & 0.66 & 0.4166 \\
& $2011-2012$ & 0.59 & 0.61 & 0.06 & 0.8065 \\
\hline
\end{tabular}

Observations were made at each site during the middle dry season (MDS, November-January) and late dry season (LDS, April-May). McNemar's test for two repeated observations on each site each year was applied to test for differences in proportions with damage. Initially, 34 sites were studied, with 15 additional sites included midway through the study 
Table 2 Annual comparisons between seasons of the proportion of sites with fresh feral swine damage (damage $\leq 1$ week in age) at sensitive wetland plant community sites on Avon Park Air Force Range, Florida

\begin{tabular}{|c|c|c|c|c|c|}
\hline \multirow[t]{2}{*}{ Sites used } & \multirow[t]{2}{*}{ Year } & \multicolumn{2}{|c|}{ Season } & \multicolumn{2}{|c|}{ McNemar's test } \\
\hline & & MDS & LDS & $\chi^{2}(1 \mathrm{df})$ & $\mathrm{p}$ \\
\hline \multirow[t]{2}{*}{ Initial 34} & 2008-2009 & 0.62 & 0.06 & 19.00 & 0.0001 \\
\hline & 2009-2010 & 0.18 & 0.24 & 0.33 & 0.5657 \\
\hline \multirow[t]{2}{*}{ All 49} & 2010-2011 & 0.27 & 0.12 & 3.77 & 0.0522 \\
\hline & $2011-2012$ & 0.14 & 0.06 & 2.00 & 0.1573 \\
\hline
\end{tabular}

Observations were made at each site during the middle dry season (MDS, November-January) and late dry season (LDS, April-May). McNemar's test for two repeated observations on each site each year was applied to test for differences in proportions with damage. Initially, 34 sites were studied, with 15 additional sites included midway through the study

Table 3 A comparison among years of the proportion of sites with any feral swine damage and the proportion of sites with fresh feral swine damage (damage $\leq 1$ week in age) within the middle dry season (MDS, November-January) and within the late dry season (LDS, April-May) for 34 sensitive plant community sites observed each year at Avon Park Air Force Range, Florida

\begin{tabular}{|c|c|c|c|c|}
\hline \multirow[t]{3}{*}{ Year } & \multicolumn{2}{|c|}{ Proportion with any damage } & \multicolumn{2}{|c|}{ Proportion with fresh damage } \\
\hline & \multicolumn{2}{|l|}{ Season } & \multicolumn{2}{|l|}{ Season } \\
\hline & MDS & LDS & MDS & LDS \\
\hline 2009 & 0.824 & 0.353 & 0.618 & 0.059 \\
\hline 2010 & 0.765 & 0.529 & 0.176 & 0.235 \\
\hline 2011 & 0.588 & 0.735 & 0.265 & 0.118 \\
\hline 2012 & 0.500 & 0.647 & 0.118 & 0.029 \\
\hline 2013 & 0.618 & NA & 0.235 & NA \\
\hline$\chi^{2}$ statistic & 13.47 & 18.749 & 25.72 & 8.62 \\
\hline$\chi^{2} \mathrm{df}$ & 4 & 3 & 4 & 3 \\
\hline $\mathrm{p}$ value & 0.0002 & 0.0017 & $<0.0001$ & 0.0348 \\
\hline
\end{tabular}

Observations during the LDS were not made in 2013

\section{Potential factors affecting risk of rooting behavior}

The effect of having high quality cover for feral swine nearby a plant community site was clear cut. Of the original 34 sites, five of the six sites within $50 \mathrm{~m}$ of canopied habitats (bayheads, swamps, hammocks, or dense pine plantations) had damage at every assessment in both the MDS and LDS time frames. The only plant community site within $50 \mathrm{~m}$ of canopied habitats to not have damage at every observation occasion had damage at every MDS assessment and 2 of its 4 LDS assessments. Two of the 15 additional sites included beginning with the fourth observation period (LDS 2010) were within $50 \mathrm{~m}$ of canopied habitats, and both of these sites had damage at every observation period in both the MDS 


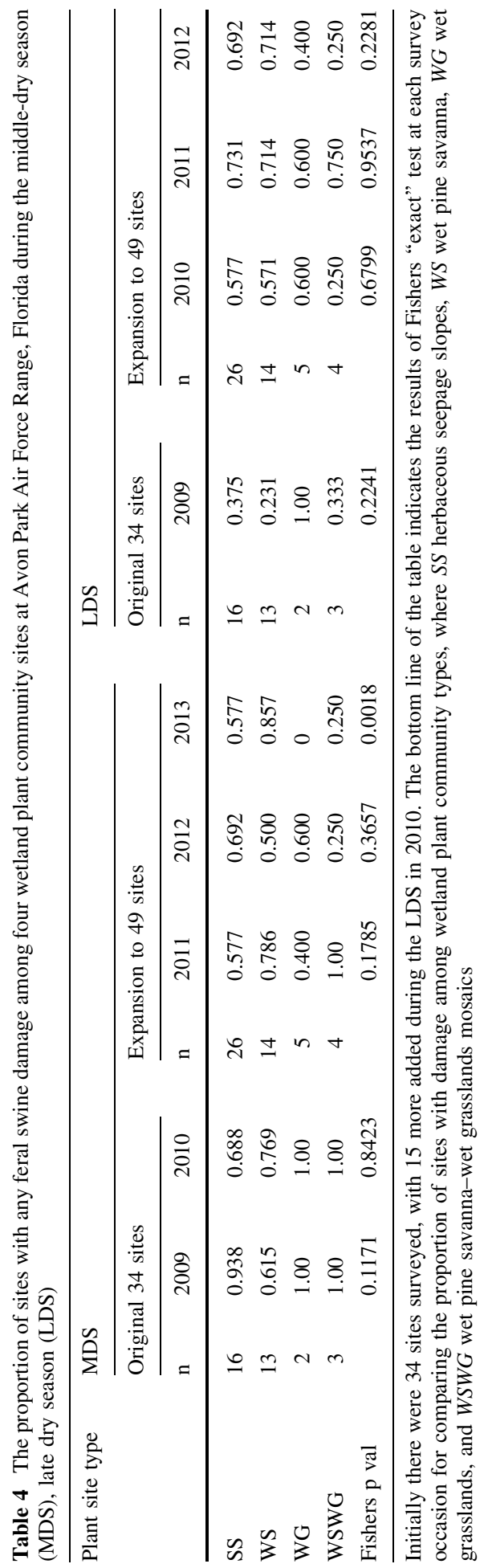




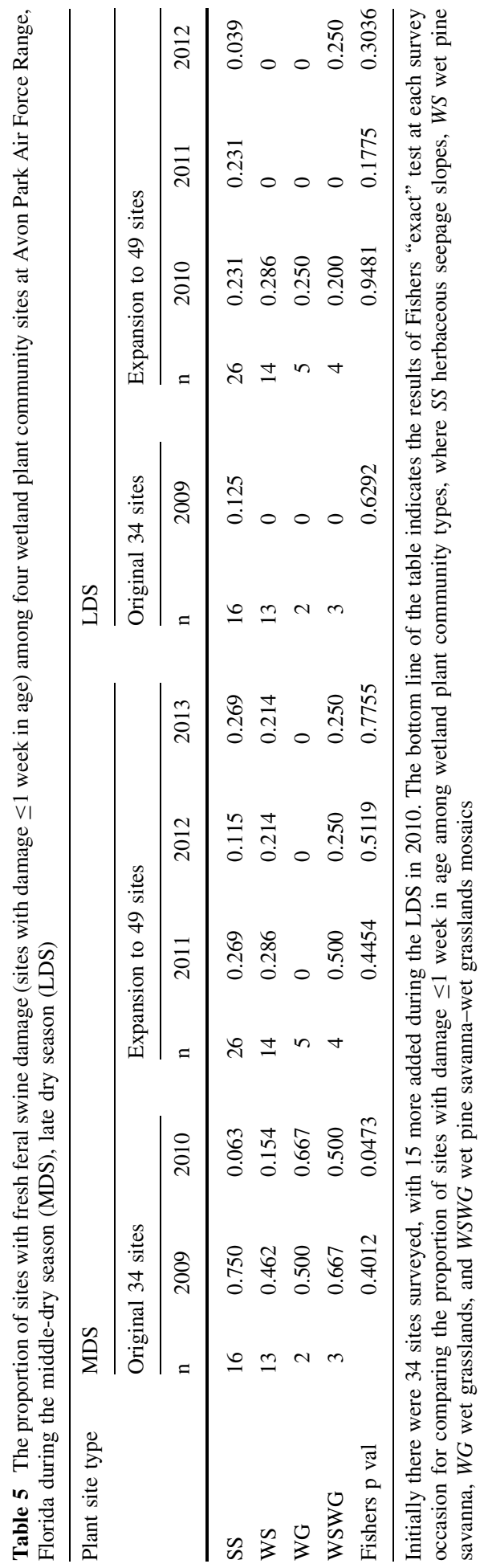


and LDS. Thus, being within $50 \mathrm{~m}$ of canopied habitats appeared to be an important risk factor for damage.

Within each year and season sampling occasion, a relatively small proportion of the sites had a wildfire or prescribed burn timed so that the effects of the fire might influence the probability of observing rooting. Even so, the sites affected by fire were rooted in nearly the same proportion as the overall number of sites. For example, in the LDS for 2010, 27 of the total 49 total sites had damage (55\%), and 3 of the 6 potentially affected by fire had damage $(50 \%)$. However, that we did not identify a relationship between recent fire and rooting does not mean one might exist. We attempted post hoc to extract indications of a relationship based on records on timing of prescribed and wildfire ignitions in areas containing the plant community sites. A multitude of variables can affect fire intensity and the total area burned within a particular site, as some sites burned more completely than others. This made determination of whether a site was recently burned or not an unreliable predictor of attractiveness for swine rooting behavior. That said, we could not measure or obtain data on within-site burn intensity, which can vary even within a specific prescribed ignition from scorch to full consumption of the above ground biomass. Nor did we have accurate spatial coverage of burnt area within a particular site beyond simple generalized burn polygons. A separate study would be needed to adequately identify relationships between burning and fire intensity with rooting likelihood or amount, or between time since fire with rooting. Such a study would involve thorough post-burn assessments as well as monitoring for swine damage at more closely spaced time intervals than were applied in this study.

Because close proximity to canopied habitats was a risk factor resulting in near-certain damage at each observation occasion, we excluded those sites from analyses of whether being near the north border was a risk factor for increased probability of damage. Two of the nine original sites within $1.6 \mathrm{~km}$ of the north border and 4 of the 25 original sites from the rest of the base fell into this category. The mean proportion of sampling occasions where damage was observed for sites near the north border was slightly higher $(0.62)$ than for sites throughout the rest of the base (0.52), though those differences were not detectable statistically $(\mathrm{t}=0.93, \mathrm{df}=26, \mathrm{p}=0.36)$.

\section{Amounts of damage within sites}

The results presented thus far on the proportion of sites with any damage or just fresh damage were also generally reflected when analyzing the amount (area) and proportion of area damaged within the sites, both when considering all damage and only the damage $\leq 1$ week in age. For the amount rooted during the MDS, differences were not indicated among plant community types $(\mathrm{F}=0.94$, $\mathrm{df}=3,30, \mathrm{p}=0.4335)$, years $(\mathrm{F}=1.23$, $\mathrm{df}=4,120, \mathrm{p}=0.3021)$, and the year $\times$ plant community type interaction $(\mathrm{F}=1.02$, $\mathrm{df}=12,120, \mathrm{p}=0.4373)$. For the LDS surveys, no differences were indicated among plant community type $(\mathrm{F}=0.94, \mathrm{df}=3,30, \mathrm{p}=0.4354)$ and the year $\times$ plant community type interaction $(\mathrm{F}=1.04, \mathrm{df}=9,90, \mathrm{p}=0.4134)$. However, a difference was found among years $(\mathrm{F}=3.98, \mathrm{df}=3,90, \mathrm{p}=0.0103)$. The mean amount rooted for years 2009 , 2010, and 2011 were, respectively $0.019,0.034$ and 0.059 (ha), whereas the mean area damaged for 2012 was 0.103 (ha).

For the proportion of a site rooted during the MDS, no differences were again indicated among plant community types $(\mathrm{F}=2.32$, df $=3,30, \mathrm{p}=0.0958)$, years $(\mathrm{F}=0.57$, $\mathrm{df}=4,120, \mathrm{p}=0.6880)$, and the year $\times$ plant community type interaction $(\mathrm{F}=0.84$, $\mathrm{df}=12,120, \mathrm{p}=0.6118)$. For the LDS, no differences were found for plant community 
type $(\mathrm{F}=1.43, \mathrm{df}=3,30, \mathrm{p}=0.2543)$ and the year $(\mathrm{F}=1.72, \mathrm{df}=3,90, \mathrm{p}=0.1683)$, but differences were indicated in their interaction $(\mathrm{F}=1.93 \mathrm{df}=9,90, \mathrm{p}=0.0575)$. All year $\times$ plant community type combinations had $<0.1 \%$ damage except for the 2011 wet grassland (1.00\%), the 2012 wet grassland (1.74\%), and 2012 wet pine savanna $(5.38 \%)$.

\section{Discussion}

\section{Population control and damage}

The impacts of feral swine population control on damage rates and amounts cannot be appropriately discussed without first reviewing the effects of the control program on the feral swine population levels (see Engeman et al. 2014). Using three population metrics, that study found that the feral swine population dropped sharply following the onset of control into 2009 and then remained considerably lower from 2010 to 2012 than in 2008 (pre-control) and in 2009 (Engeman et al. 2014). However, the minimum population values for all three metrics occurred in 2010 or 2011, but increased from 2011 to 2012 (Engeman et al. 2014). Two important messages emerged from those results. First, control appeared to reduce feral swine populations beyond that provided by recreational hunting. While recreational hunting imposes a source of mortality to feral swine populations, hunters do not target all population demographics equally, potentially limiting the severity of population reduction (Braga et al. 2010; Festa-Bianchet 2007; Keuling et al. 2013; Plhal et al. 2011). In contrast, a control program targets all demographics and typically is cost-effective (Engeman et al. 2003, 2004b, 2007a, b, 2010), yet it requires consistent application to be effective (Engeman et al. 2014). Second, the efficacy of control as applied at APAFR decreased the population to a point, but did not sustain a continued decline, due primarily to limitations on the control effort during hunting seasons, permitting issues, restricted access due to military missions (Engeman et al. 2014). Even though the population had been reduced, the remaining feral swine persistently rooted the sensitive plant sites, as was evidenced by the mixed trends for the proportion of sites with any damage between the MDS and LDS. Nevertheless, there appeared to be a reduction in the proportion of sites with fresh damage at any given time, which could be a first step toward reducing overall the proportion of sites with damage and also the amount of damage. Detecting reductions in amounts of damage was challenging because both the total rooted area and percentage of the total area rooted at a plant community site rooted at each occasion were typically small (e.g., well lower than pre-control damage levels observed elsewhere in seepage slopes; Engeman et al. 2007b).

\section{Considerations for protecting the rare plant communities from damage}

The intended effects of control on the feral swine population at APAFR appeared not to have been fully realized due to limitations on the application of control measures each year (Engeman et al. 2014). The results presented here on feral swine damage to the sensitive plant community sites through a five-year course of feral swine control reflect a lack of sustained cumulative impacts to the feral swine population. Thus going forward, what is the best strategy to protect the globally imperiled species and plant communities from feral swine damage? One approach would be to combine swine-proof fencing with interior removal of feral swine. Most of the sensitive plant sites are relatively small in area. 
Fencing individual sites is not a practical nor an ecologically sound option, although an APAFR archaeological site of substantial significance was fenced to prevent damage (Engeman et al. 2013a). Fencing numerous sites would interfere with application of prescribed burns since fencelines would need protection from being destroyed by frequent fire, which in turn would disrupt the spread of fire. Disrupting the spread of fire across the native landscape of otherwise intact pyrogenic ecosystems would present a serious impediment critical to maintaining the savanna-grassland ecosystem (Platt et al. 2015). A partial, but viable resolution, if economically feasible, would be to erect swine-proof fencing around the restricted access military impact areas (areas subject to military mission ignitions, but closed to public access or hunting) at APAFR that comprise ca 8633 ha with intact groundcover vegetation. Once secure from feral swine immigration, eradication of feral swine within the fenced impact areas could ultimately eliminate rooting damage to sensitive resources within these areas (Fig. 2). The impact areas are subject to frequent fires and are already surrounded by barbed wire fencing (which is not a sufficient barrier to feral swine movement) to exclude access to the general public and other unauthorized personnel due to unexploded ordnance and ongoing incendiary military exercises. Swine proof fencing (known commonly as hog wire) could be erected on these existing fences at considerable labor and material cost savings compared to constructing entirely new "hog wire" fencelines. Nine of our study sites were within the military impact areas, including six of the most chronically damaged sites. Many more rare plant community sites are in the

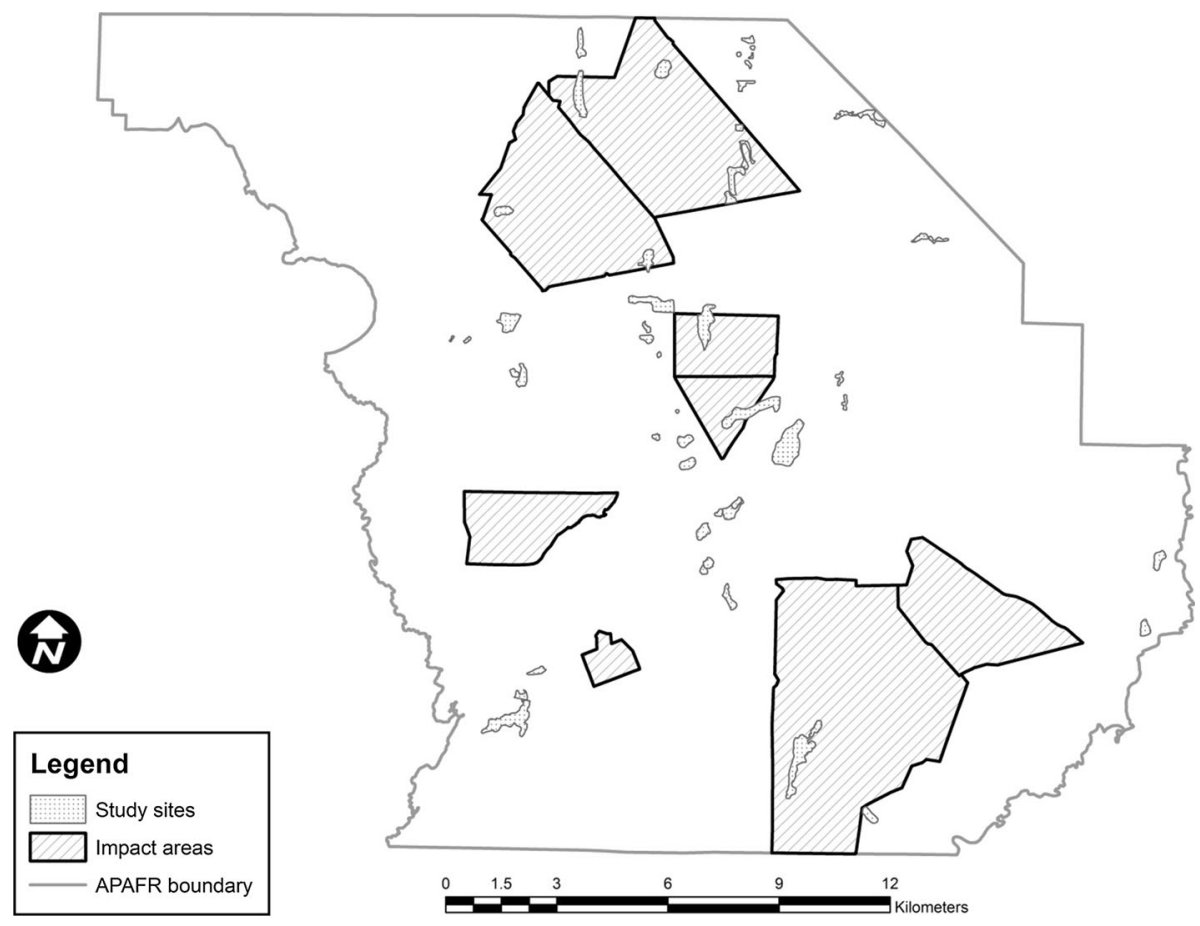

Fig. 2 The location of 49 feral swine rooting survey sites at Avon Park Air Force Range, located in south central Florida are shown relative to restricted access, military impact areas where live military fire takes place. Many other sensitive plant community sites exist on the base both inside and outside the restricted areas, but were not included in our study 
restricted areas that we did not include in our study because of access issues. Moreover, hog-proofing the existing fencing around the restricted impact areas and eradicating the feral swine within them would not affect recreational hunting. Rather, it would (1) provide long-term protection for frequently damaged sites, (2) protect multiple archaeological sites, (3) drastically reduce the need for trappers to enter restricted zones once cleared of feral swine, and (4) alleviate scheduling difficulties for feral swine control during military exercises.

Fencing does not appear to be a tenable solution for excluding feral swine from the unrestricted natural areas of APAFR. It would be cost-prohibitive and impractical to create a functional barrier through swamps, river bottoms, ponds and other obstacles to maintaining a "hog proof" fenceline. Considerable effort and costs would be required to maintain zero immigration through fences. Damage from tree-fall due to high winds, rainfall from tropical systems, and annual wet season high rainfall events would inundate parts of a fenceline rendering it permeable to feral swine. Thus, reducing or preventing damage to special plant communities will likely be dependent upon repeated and unrelenting control of the feral swine population. Feral swine control has been found to be highly cost-effective elsewhere for protecting special plant communities (Engeman et al. 2003, 2004b, 2007a, b), and would likely be so at APAFR if consistently applied. In Florida, feral swine are ubiquitous and pose a constant threat of immigration into nearby areas where their populations have been reduced by control efforts. Also, feral swine have the highest reproductive potential of any large mammal in North America (Wood and Barrett 1979; Hellgren 1999), and the beneficial effects of feral swine population reduction can be quickly undone. Thus, feral swine control would have to be a permanent management action through time, with the level of control effort that would not eliminate recreational hunting of feral swine at APAFR. Concomitantly, the application of control should be able to be dependably applied through the year, especially in consideration of a constant threat of immigration. Accomplishing this would require close coordination with recreational hunting programs (when swine control is prohibited), and might also require development of innovative new control tools that could be applied without conflicting with recreational hunting.

\section{Quantifying damage}

For our study we used very precise GPS measurements and GIS mapping to accurately measure damage at each site. There are also methods now available that are not as "fieldintensive" that can provide high-quality estimates of damage within a site (Thomas et al. 2013). However, to monitor a substantial number of sites over time as we have done requires human resources that are unlikely to be available in many damage assessment circumstances. Thus, we also examined the proportion of sites with any damage or with fresh damage, not only as a low-labor gauge for assessing need for and efficacy of a control program, but also to readily consider patterns of damage that also might be used for managing swine and protecting natural resources. This approach is similar to that proposed as an indicator for invasive species across geographical units on a large landscape (Meyerson et al. 2008). Assessing sites for presence-absence of damage doesn't assess the magnitude of damage within sites, but it is a lower-labor means that provides a quantitative damage assessment that can cover a much larger area with less labor intensity. This could be especially useful when considering whether to apply a management action and how extensive it should be. In the global picture of combating swine damage, the sites would not have to be wetland plant communities. They could be agricultural units (fields, 
pastures, farms, counties, etc. as potential units of scale), endangered species sites (e.g., nesting beaches or other breeding sites), archaeological sites, and many other possibilities. For whatever unit resource in need of protection from swine damage, looking at the proportion of sites with damage (especially) and the proportion of sites with fresh damage (if possible) would provide one means to assess the need and efficacy of management actions from year to year. The investigators must decide on the damage assessment approach that best meets objectives while remaining within available labor resources.

\section{Resource value}

When considering the optimal application of resources for protecting the natural treasures at APAFR, an economic perspective that examines the cost of swine damage to plant communities might be useful. One defensible, logical valuation for damaged habitat that has been applied to Florida wetlands uses expenditure data for permitted mitigation projects. Such data represent an empirical demonstration of willingness-to-pay value, and they are generally available for many wetland habitats. King (1998) assessed dollar values perunit-area spent in efforts to restore various wetland habitat types. The values represent the U.S. dollar amounts that environmental regulators, and to a degree elected governments, have allowed permit applicants to spend in attempts to replace lost wetland services and values (King 1998). Use of these figures, coupled with appropriate adjustments for annual rates of inflation (Zerbe and Dively 1994), produces credible habitat valuations. This approach has been successfully applied to other special, protected wetlands damaged by swine in Florida (Engeman et al. 2003, 2004a, b, 2007b). Because the wetland plant community sites we studied at APAFR are uncommon (globally imperiled), they are not specifically listed in the general survey categories provided by King (1998). Therefore, as done previously for valuing swine damage to unique wetlands in Florida (e.g., Engeman et al. 2007b), we used the median figure from King (1998) over the listed freshwater wetland types (excluding prairie potholes and riverine emergent) as an empirical "willingness to pay" value for restoration (see Engeman et al. 2007b for another example). The 2013 (end of study) value for this restoration cost estimate after adjusting for a $3 \%$ annual rate of inflation since the date of the values presented in King (1998) was \$491,775/ha (Zerbe and Dively 1994; King 1998).

There are over 22,000 ha of land of statewide natural area significance at APAFR (Orzell 1997). Assuming the observed damage at our study sites (587 combined ha across all 49 sites) is representative of swine damage across all significant wetland areas at APAFR, we extrapolated our observed extremes in proportional area damaged and associated value across the entire 22,000 ha. The year and season with the minimum mean proportion damaged across all of our sample sites was 2009 LDS with an average $0.17 \%$ of site area damaged. The year and season with the maximum mean proportion damaged across all sample sites was 2012 LDS with an average $1.90 \%$ of site area damaged. Thus, we extrapolate that between 37.4 and 418 total ha of the 22,000 ha of significant natural areas were damaged at any given time during our study. Viewed in this fashion, the associated total value of feral swine damage to all sensitive plant community sites at APAFR ranged from $\$ 18,392,385$ in 2009 LDS to $\$ 205,561,950$ in 2012 LDS. This demonstrates that even proportionally low damage amounts across a large area (22,000 ha) can produce a large accrued value for the damage. The sites assessed for valuation of damage in previous studies using the same valuation method involved total areas ranging from 13.6 ha (Engeman et al. 2004b) to 122.3 ha (Engeman et al. 2007b). The orders of magnitude in greater values of total estimated damage here reflects orders of magnitude 
larger wetland area of significance at APAFR. Economics figures prominently in management, such as fencing and swine control efforts, and an economic measure of magnitude of the damage allows the costs for management actions to be weighed against the costs of the damage. Such economic information promotes the efficient and effective allocation limited conservation funds (Engeman et al. 2004a).

Acknowledgments We appreciate the support of Paul Ebersbach, Chief, Environmental Flight, APAFR, and the USAF for funding this project. For field assistance, we are grateful to J. S. Humphrey, S. Koontz, W. E. Bruce, K. L. Keacher, and E. Fetzer. We appreciate the GIS support provided by Casey Lindemuth for assembling spatial data used extensively in this study. This research was supported through interagency agreement 08-7483-0707(IA) between the National Wildlife Research Center and Avon Park Air Force Range.

\section{References}

Ashtech (formerly Magellan Professional) (2009) MobileMapping. Mobile Mapper Office, Santa Clara. http://www.ashtech.com

Baber DW, Coblentz BE (1987) Diet, nutrition, and conception in feral pigs on Santa-Catalina Island. J Wildl Manag 51:306-317

Beckage B, Platt WJ, Slocum MG, Panko B (2003) Influence of the El Niño-Southern Oscillation on the fire regimes of the Florida Everglades. Ecology 84:3124-3130

Boughton EH, Boughton RK (2014) Modification by an invasive ecosystem engineer shifts a wet prairie to a monotypic stand. Biol Invasions 16:2105-2114

Braga C, Alexandre N, Fernandez-Llario P, Santos P (2010) Wild boar (Sus scrofa) harvesting using the espera hunting method: side effects and management implications. Eur J Wildl Res 56:465-469

Bratton SP (1977) Wild hogs in the United States-origin and nomenclature. In: Wood GW (ed) Research and Management of Wild Hog Populations. Baruch Forest Science Institute of Clemson University, Georgetown, South Carolina, The Belle W, pp 1-4

Bratton SP, Harmon ME, White PS (1982) Patterns of European wild boar rooting in the western Great Smoky mountains. Castanea 47:230-242

Brenner J (1991) Southern Oscillation anomalies and their relationship to Florida wildfire. Fire Manag Notes $52: 28-32$

Bridges EL, Orzell SL (1999) Cutthroat grass communities. In: South Florida Multi-Species Recovery Plan. U.S. Fish and Wildlife Service, Atlanta, pp 3-347-3-398

Chavarria PM, Lopez RR, Bowser G, Silvy NJ (2007) A landscape-level survey of feral hog impacts to natural resources of the Big Thicket National Preserve. Hum Wildl Confl 1:199-204

Chen E, Gerber JF (1990) Climate. In: Myers RL, Ewel JJ (eds) Ecosystems of Florida. University of Central Florida Press, Orlando, pp 11-35

Choquenot D, McIlroy J, Korn T (1996) Managing vertebrate pests: feral pigs. Australian Government Publishing Service, Canberra, Bureau of Resource Sciences

Cole RJ, Litton CM, Koontz MJ, Loch RK (2012) Vegetation recovery 16 years after feral pig removal from a wet Hawaiian forest. Biotropica 44:463-471

Conger TH, Young E, Heckmann RA (1999) Brucella suis in feral swine. In: Proceedings of the 1999 National Feral Swine symposium. Texas Animal Health Commission, Austin, pp 98-107

Corn JL, Cumbee JC, Chandler BA, Stallknecht DE, Fischer JR (2005) Implication of feral swine expansion: expansion of feral swine in the United States and potential implication for domestic swine. Feral Swine Subcommittee on Brucellosis and Pseudorabies. United States Animal Health Association, St. Joseph, pp 295-297

Cushman JH, Tierney TA, Hinds JM (2004) Variable effects of feral pig disturbances on native and exotic plants in a California grassland. Ecol Appl 14:1746-1756

Donders TH, Wagner F, Dilcher D, Visscher H (2005) Mid to late Holocene El Nino-Southern Oscillation dynamics reflected in the subtropical terrestrial realm. Proc Natl Acad Sci 102:10904-10908

Donders TH, de Boer HJ, Finsinge W, Grimm EC, Dekker SC, Reichart GJ, Wagner-Cremer F (2011) Impact of the Atlantic Warm Pool on precipitation and temperatures in Florida during the North Atlantic cold spells. Clim Dyn 36:109-118 
Ebersbach PL, Orzell SL, Fredlake M, Olsen K, Bonner B, Zeichel T, Schofield B, Hersberger T (2013) Integrated Natural Resources Management Plan, USAF, Avon Park Air Force Range, Florida. Unpublished Report

Engeman RM, Smith HT, Shwiff SA, Constantin BU, Nelson M, Griffin D, Woolard J (2003) Prevalence and economic value of feral swine damage to native habitat in three Florida state parks. Environ Conserv 30:319-324

Engeman RM, Shwiff SA, Smith HT, Constantin BU (2004a) Monetary valuation of rare species and imperiled habitats as a basis for economically evaluating conservation approaches. Endangered Species Update 21:66-73

Engeman RM, Smith HT, Severson R, Severson MA, Woolard J, Shwiff SA, Constantin BU, Griffin D (2004b) Damage reduction estimates and benefit-cost values for feral swine control from the last remnant of a basin marsh system in Florida. Environ Conserv 31:207-211

Engeman RM, Constantin BU, Shwiff SA, Smith HT, Woolard J, Allen J, Dunlap J (2007a) Adaptive and economic management methods for feral hog control in Florida. Hum Wildl Confl 1:178-185

Engeman RM, Stevens A, Allen J, Dunlap J, Daniel M, Teague D, Constantin BU (2007b) Feral swine management for conservation of an imperiled wetland habitat: Florida's vanishing seepage slopes. Biol Conserv 134:440-446

Engeman RM, Constantin BU, Hardin S, Smith HT, Meshaka WE Jr (2009) “Species pollution” in Florida: a cross-section of invasive vertebrate issues and management responses. In: Wilcox CP, Turpin RB (eds) Invasive species: detection, impact and control. Nova Science Publishers, Hauppauge, pp 179-197

Engeman RM, Duffiney A, Braem S, Olsen C, Constantin BU, Small P, Dunlap J, Griffin JC (2010) Dramatic and immediate improvements in insular nesting success for threatened sea turtles and shorebirds following predator management. J Exp Mar Biol Ecol 395:147-152

Engeman RM, Couturier KJ, Felix RK Jr, Avery ML (2013) Feral swine disturbance at important archaeological sites in Florida. Environ Sci Pollut Res 20:4093-4098

Engeman RM, Hersberger T, Orzell SL, Felix RK Jr, Killian G, Woolard J, Cornman J, Romano D, Huddleston C, Zimmerman P, Barre C, Tillman EA, Avery ML (2014) Impacts from control operations on a recreationally hunted feral swine population at a large military installation in Florida. Environ Sci Pollut Res 21:7689-7697

ESRI (2011) ArcGIS Desktop 10. Redlands. http://www.esri.com

Felix RK Jr, Orzell SL, Tillman EA, Engeman RM, Avery ML (2014) Fine-scale, spatial and temporal assessment methods for feral swine disturbances to sensitive plant communities in south-central Florida. Environ Sci Pollut Res 21:10399-10406

Festa-Bianchet M (2007) Ecology, evolution, economics and ungulate management. In: Fullbright T, Hewitt D (eds) Wildlife science: linking ecological theory and management applications. CRC, Boca Raton, pp 183-202

Florida Natural Areas Inventory (FNAI) (2010) Guide to the natural communities of Florida. Florida Natural Areas Inventory and Florida Department of Natural Resources, Tallahassee

Gipson PS, Hlavachick B, Berger T, Lee CD (1997) Explanations for recent range expansions by wild hogs into midwestern states. In: Proceedings of great plains wildlife damage control workshop, vol 13, pp $148-150$

Groot Bruinderink GWTA, Hazebroek E (1996) Wild boar (Sus scrofa scrofa L.) rooting and forest regeneration on podzolic soils in the Netherlands. For Ecol Manag 88:71-80

Hardin S (2007) Managing non-native wildlife in Florida: state perspective, policy and practice. In: Witmer G, Pitt W, Fagerstone K (eds) Managing vertebrate invasive species: proceedings of an international symposium. USDA/APHIS/WS National Wildlife Research Center, Fort Collins, pp 43-52

Hellgren E (1999) Reproduction in feral swine. In: Proceedings of the 1999 national feral swine symposium. Texas Animal Health Commission, Austin, pp 67-68

Hone J (1988) Feral pig rooting in a mountain forest and woodland distribution, abundance, and relationships with environmental variables. Aust J Ecol 13:393-400

Joppa LN, Roberts DL, Myers N, Pimm SL (2011) Biodiversity hotspots house most undiscovered plant species. Proc Natl Acad Sci USA 108:13171-13176

Keuling O, Baubet E, Duscher A, Ebert C, Fischer C, Monaco A, Podgórski T, Prevot C, Ronnenberg K, Sodeikat G, Stier N, Thurfjell H (2013) Mortality rates of wild boar Sus scrofa in central Europe. Eur J Wildl Res 59:805-814

King D (1998) The dollar value of wetlands: trap set, bait taken, don't swallow. National Wetlands Newsletter, July-August, pp 7-11

Kotanen PM (1995) Responses of vegetation to a changing regime of disturbance: effects of feral pigs in a Californian coastal prairire. Ecography 18:190-199 
Meyerson LA, Engeman RM, O’Malley R (2008) Tracking non-native vertebrate species: indicator design for the United States. Wildl Res 35:235-241

Myers RL, Ewel JJ (eds) (1990) Ecosystems of Florida. University of Central Florida Press, Orlando

Noss RF, Platt WJ, Sorrie BA, Weakley AS, Means DB, Costanza J, Peet RK (2015) How global biodiversity hotspots may go unrecognized: lessons from the North American coastal plain. Divers Distrib 13:1-9

Orzell SL (1997) Natural areas inventory of Avon Park Air Force Range in Polk and Highlands counties Florida. Unpublished report to US Air Force

Orzell SL, Bridges EL (2006a) Floristic composition and species richness of subtropical seasonally wet Muhlenbergia sericea prairies in portions of Central and South Florida. In: Noss RF (ed) Land of fire and water: the Florida Dry Prairie Ecosystem. Proceedings of the Florida Dry Prairie conference, 5-7 October 2004, Sebring, pp 136-175

Orzell SL, Bridges EL (2006b) Species composition and environmental characteristics of Florida dry prairies from the Kissimmee River region of south-central Florida. In: Noss RF (ed) Land of fire and water: the Florida Dry Prairie Ecosystem. Proceedings of the Florida Dry Prairie conference, 5-7 October 2004, Sebring, pp 100-135

Platt WS, Orzell SL, Slocum M (2015) Seasonality of fire weather strongly influences fire regimes in South Florida savanna-grassland landscapes. PLoS ONE 10(1):e0116952

Plhal R, Kamler J, Homolka M, Adamec Z (2011) An assessment of the applicability of photo trapping to estimate wild boar population density in a forest environment. Folia Zool 60(3):237-246

Rodgers L, Black D, Bodle M, Laroche F (2014) The status of nonindigenous species in the South Florida environment. In: 2014 South Florida Environmental Report, vol I, chap 7. South Florida Water Management District, West Palm Beach, pp 7-1-7-53

Romero CH, Meade PN (1999) Pseudorabies virus in feral swine: a research update. In: Proceedings of the 1999 National Feral Swine symposium. Texas Animal Health Commission, Austin, pp 73-74

Seward N, VerCauteren K, Witmer G, Engeman RM (2004) Feral swine impacts on agriculture and the environment. Sheep Goat Res J 19:34-40

Slocum MG, Orzell SL (2013) A structural equation model analysis of relationships among ENSO, seasonal descriptors and wildfires. PLoS ONE 8(9):e75946

Slocum MG, Platt WJ, Beckage B, Orzell SL, Taylor W (2010) Accurate quantification of seasonal rainfall and associated climate-wildfire relationships. J Appl Meteorol Climatol 49:2559-2573

Sorrie BA, Weakley AS (2001) Coastal plain vascular plant endemics: phytogeographic patterns. Castanea 66:50-82

Sorrie BA, Weakley AS (2006) Conservation of the endangered Pinus palustris ecosystem based on coastal plain centres of plant endemism. Appl Veg Sci 9:59-66

Stein BA, Scott C, Benton N (2008) Federal lands and endangered species: the role of military and other federal lands in sustaining biodiversity. BioScience 58:339-347

Taft AC (1999) Feral swine-national concerns. In: Proceedings of the 1999 National Feral Swine Symposium. Texas Animal Health Commission, Austin, pp 25-26

Taylor RB, Hellgren EC (1997) Diet of feral hogs in the western South Texas Plains. Southwest Nat 421:33-39

Thomas J, Engeman RM, Tillman EA, Fischer JW, Orzell SL, Glueck DH, Felix RK Jr, Avery ML (2013) Optimizing line intercept sampling and estimation for feral swine damage levels in ecologically sensitive wetland plant communities. Environ Sci Pollut Res 20:1503-1510

Towne CW, Wentworth EN (1950) Pigs from Cave to Cornbelt. University of Oklahoma Press, Norman

Trimble (2008) TerraSync. GPS Pathfinder Office, Sunnyvale. http://www.trimble.com

U.S. Department of Agriculture (1999) Wild pigs hidden danger for farmers and hunters. Animal and Plant Health Inspection Services Information Bulletin 620, Washington, DC

Wood GW, Barrett RH (1979) Status of wild pigs in the United States. Wildl Soc Bull 7:237-246

Zerbe RO, Dively DD (1994) Benefit-cost analysis: in theory and practice. HarperCollins College Publishers, New York 